A list of Working Papers on the last pages

No. 192,1988

JOB MOBILITY AND SUBSEQUENT WAGES IN SWEDEN

by

Anders Björklund and Bertil Holmiund

This is a preliminary paper. It is intended for private circulation and should not be quoted or referred to in publications without permission of the author. Comments are welcome.

Apri1, 1988 


\section{JOB MOBILITY AND SUBSEQUENT WAGES IN SWEDEN}

by

Anders Björklund ${ }^{*}$ and Bertil Holmlund ${ }^{* *}$

March 1988

This paper was presented at "An International Conference on Migration and Labor Market Efficiency", Knoxville, Tennessee, October 15-17, 1987.

* Institute for Social Research

University of Stockholm

S-106 91 Stockholm, SWEDEN

and

IUI

Grevgatan 34

S-114 53 Stockholm, SWEDEN
** Department of Economics Uppsala University, Box 513

and S-751 20 Uppsala, SWEDEN

FIEF

Wallingatan 38

S-111 24 Stockholm, SWEDEN 


\section{Introduction}

The Swedish approach to labor market adjustment has its intellectual origins in very influential work from the early 1950 s by trade union economists, notably Gösta Rehn and Rudolf Meidner. A basic theme of the so called Rehn-Meidner model was that adjustment of relative wages are inefficient and/or undesirable as a means to accomplish sectoral labor reallocations. According to Rehn and Meidner, labor mobility induced by relative wage changes is a slow process, and it may also have undesirable distributional consequences. The process of structural change should therefore be stimulated by deliberate actions on part of the confederation of trade unions and the government. This policy involved a "solidaristic" wage policy as well as active labor market policies.

A cornerstone of the solidaristic wage policy has been the principle of equal pay for equal work; differences in profitability between firms and sectors should not have any consequences for wage setting. As a result, inefficient firms may be driven out of business and workers laid off. The second element of the policy - the active labor market policy - should then be designed so that unemployed or unemploymentthreatened workers could find new jobs at low costs. This policy has therefore involved mobility grants and manpower training programs of a rather substantial scale.

The foundations of the Swedish policy thus rest on the hypothesis that the "pull"-incentives are slow-operating and have undesirable consequences. Deliberate actions on part of unions and the government are therefore needed, and the central element here is the solidaristic wage policy which would add strong "push"-incentives to the weak pull-forces. 
The efficiency of this Swedish model has been continuously discussed by economists and policy-makers during most of the post-war period. (It is also discussed in some detail by Flanagan (1987).) In spite of this debate, very little empirical research has illuminated the importance and consequences of pull and push-mobility. One reason for this lack of research is simply that relevant data bases have not been available. Although the 1970s have seen the appearance of very useful sets of microdata, the latter have not contained information rich enough to distinguish between different kinds of mobility. Some studies have nevertheless shed some light on the issues involved, and among these belong an early study by Rundblad (1964) and a more recent one by Holmlund (1984a, 1984b).

Rundblad's sociological study was based on interviews with male workers in a local labor market in the early 1960s (Norrköping). He found that about one third of the job movers stated economic motives for job mobility, whereas 20-30 percent were dissatisfied with workplace conditions. Holmlund's study made use of panel data for the period 1968-74, and he was thereby able to provide information on the role of income prospects for job mobility. A consistent finding was that relative wages matter for job mobility, and that job movers in general received wage gains from moving. Holmlund could however not satisfactorily distinguish between different types of job mobility, although he attempted to restrict the study to voluntary mobility by excluding individuals with unemployment experiences during the period of investigation.

The purpose of this study is to extend earlier Swedish studies on mobility and wages by using a new micro data base, the so called HUS-data. This data set includes two panels from 1984 and 1986, and contains novel and detailed information on the nature of job mobility and migration. Section II offers an informal discussion of some theoretical issues, in particular the relevance of distinguishing between quits 
and layoffs. Section III proceeds to a description of the data base, and provides information on push and pull motives for mobility decisions in Sweden. The consequences of job mobility are analyzed in Section IV.

\section{Theoretical Issues}

Several models of individual wage growth generate predictions about job turnover and wage gains to mobility. For example, Burdett (1978) presents a partial equilibrium search model where workers face a common distribution of wage offers and are allowed to engage in on-the-job search and influence the arrival rate of job offers by the choice of search effort. The worker's wage is constant on any particular job, but may increase through job changes. The worker quits if an offer arrives that involves a higher pay than the worker's current wage. Burdett's model does not incorporate investment in human capital; yet it implies that wages grow over the life cycle through wage gains associated with job mobility.

In Burdett's model - which ignores moving costs - the worker's reservation wage is equal to his current wage, and wage gains are always implied by a quit decision. Other models admit the possibility that a worker may take a wage cut to accept a job offer. Holmlund and Lang (1985) consider a model where jobs carry nonwage attributes that are unobserved when the job acceptance decision is made. If moving costs are negligible, a worker is willing to accept a fall in his current wage in order to participate in the "job change lottery." A job change carries the option of a favorable realization of the nonwage attribute, and the worker may be willing to pay for this option.

Search models of the type outlined above do not have much to say about job separations initiated by the employer. Mortensen (1978) considers a matching model 
where both the worker and the employer are engaged in search for better opportunities. Mortensen compares noncooperative and cooperative solutions to the workeremployer game. In the noncooperative solution, each agent chooses a search intensity that maximizes its own expected wealth, taking the other agent's choice as given. The worker's quit decision then ignores that a quit may cause a capital loss to the firm; likewise, the firm's dismissal of a worker ignores the effect its action may have on the worker's expected wealth. This noncooperative solution yields the familiar prediction that the quit rate decreases with the worker's share of the capital value of the match; analogously, the dismissal rate decreases with the firm's share of the capital value. (Cf. also Parsons, 1972.)

A cooperative solution, by contrast, recognizes that coordination may increase the payoffs to both the worker and the employer. Search intensities and acceptance rules are then chosen so that the total joint wealth is maximized. It turns out that both the quit rate and the dismissal rate decreases with the capital value of the match, and are independent of the division of the rents from the match.

An important empirical implication from the joint wealth maximization hypothesis is that quit and dismissal rates are independent of the wage rate, holding constant the capital value of the match. Labor turnover is a process whereby worker-job matches are improved, and the distinction between worker-initiated and employer-initiated job separations become artificial under joint wealth maximization. This hypothesis is also suggested by Borjas and Rosen (1980), who argue (p. 163) that "the analysis of job mobility should be conducted by comparing the individual's current productivity to the best alternative."

In this paper we attempt to shed some light on whether "it is irrelevant who initiates the separation." (Borjas and Rosen, p. 178.) We focus on wage growth for 
workers who quit, become laid off, or don't change jobs. To the extent that the wage serves as a proxy for the capital value of the match, wage gains should be expected for job separations in general, irrespective of the form of the separation.

\section{The Data}

\section{A. The HUS-project}

The first wave of the HUS-project aimed at the population residing in Sweden at the end of January 1984. Individuals born before 1910 or after 1965 were excluded from the sampling frame. The household to which the randomly selected individual belonged was identified. In general both the head of the household and the spouse were interviewed. If the randomly selected person was neither of these two, this third person was interviewed in addition. In the first wave of the project, 1503 households and 2636 individuals were interviewed.

The second wave of interviews was done in spring 1986. Those who were included in 1984 were asked retrospective questions about their labor market histories during the two years. The main activity during each month was reported, as well as change of employer and change of residence. For each change of employer, questions were asked about the reason for the change and the consequences. For each change of residence, questions were asked about the reason.

More detailed information about the HUS-project can be found in Klevmarken (1986). A code book with technical information is available in Swedish (Klevmarken, Olovsson and Flood (1986)).

\section{B. Job Changes in the HUS-data}

The HUS-data provides detailed event-histories of labor market transitions during the period between the two interviews in 1984 and 1986. Slightly above 10 percent 
of those who were employed at least once during this period report that they have had more than one employer (see Table 1). These job-changes took different forms, and we will distinguish between quits and layoffs in the sequel. A quit is a job change initiated by the employee, and the quitter will also be referred to as a "job leaver". A layoff is initiated by the employer, and the worker may accordingly be regarded as a "job looser".

The distinction between job leavers and job loosers is however somewhat vague, partly because of the prevalence of temporary jobs. In Sweden, jobs tend to fall in basically two categories, namely permanent and temporary jobs. The former could not be terminated at the employer's will without just cause, according to the Employment Security Act of 1974. Temporary jobs, by contrast, are jobs with a predetermined duration, typically 6 months. Temporary employment contracts may be used during a trial period, or when there is piling up of work, or when there is a need for a substitute because of temporary absenteeism from work. It is the employer who decides whether the temporary employment contract should be retained or not. We will therefore classify the termination of temporary jobs as layoffs.

The majority (70 percent) of job terminations in this data set was initiated by the employees rather than the employers (Table 1). A quit may of course be induced by the risk of loosing the job. For example, a worker on a temporary job has obvious incentives to engage in on-the-job search as $\mathrm{s} /$ he approaches the predetermined job termination date. Table 2 provides information about employment security among job quitters. It is notable that the majority of the job leavers have had a permanent rather than a temporary job. 
Table 1 Patterns of Job Mobility, 1984-86.

Number of individuals who have

worked during the period

1518

Number of workers with more

than one employer

Fraction movers

0.10

Reasons for job mobility (all moves, $\mathrm{n}=194$ )

Fraction quits (own initiative)

0.71

Fraction layoffs (employer's initiative)

0.26

Source: HUS.

Table 2

Job Quits by Type of Employment Contract, (all quits), and by Perceived Risk of Loosing the Job.

Left permanent job ${ }^{*}$ :

0.71

Left temporary job ${ }^{*}$ :

0.27

Risk of loosing a job held in spring $1984 .{ }^{*}$

$\begin{array}{llllllllllll}\text { Risk: } & 0 & 10 & 20 & 30 & 40 & 50 & 60 & 70 & 80 & 90 & 100 \\ \text { Fraction: } & 0.83 & 0.01 & 0 & 0 & 0 & 0.07 & 0.03 & 0.02 & 0.03 & 0 & 0.01\end{array}$

Notes: $\quad *$ Refers to all quits during 1984-86.

Refers to workers who were employed at the time of the interview 1984 , and who left the job (own initiative) during the subsequent two years $(\mathrm{n}=89)$.

Source: $\quad$ HUS. 
Those who were employed during the first interview were also asked to give a subjective assessment of the risk of loosing the job within one year. Table 2 shows the "ex ante risk profile" for those who subsequently left their job, and we note that very few of the job leavers reported layoff risks; in fact, 83 percent of the job leavers reported zero risk of loosing the job. This piece of evidence gives further support for the conclusion that quits are in general associated with pull-factors rather than push-motives (layoff risks).

The information in Table 3 provides a more detailed picture of quit motives. The upper part of the table reveals that factors related to the previous job are more important than factors of a personal nature. The lower part of Table 3 sets out further information about quit motives. Very few workers report a low wage as the main reason for leaving the previous job. However, it turns out that many of those who reported personal reasons for leaving jobs also stated that they moved because of a desire to get a job with higher pay. The data clearly indicate that job related factors are important for quits.

The relationship between job mobility and geographical mobility is described in Table 4. The information is confined to those who are employed both 1984 and 1986. The hypothesis of independence between job mobility and geographical mobility can be strongly rejected. This holds for residential mobility, local community (kommun) mobility, and county (län) mobility. Geographical movers have changed employer to a much larger extent than geographical stayers. Whereas only 14 percent of the job stayers are residential movers, around 40 percent of the job leavers have changed residence. The difference between the laid-off workers and the quitters is however very small. 
Table 3 Job Quits by Reasons for Quitting (all quits).

$\begin{array}{ll}\text { Working conditions } & 0.60\end{array}$

$\begin{array}{ll}\text { Personal and family reasons } & 0.34\end{array}$

$\begin{array}{ll}\text { Uncertain } & 0.06\end{array}$

\section{Working conditions}

Did not like the job, the colleagues, or the job

environment

The wage too low

$\begin{array}{ll}\text { Inconvenient working hours } & 0.14\end{array}$

$\begin{array}{ll}\text { Too much commuting } & 0.05\end{array}$

$\begin{array}{ll}\text { Other reasons/uncertain } & 0.42\end{array}$

\section{Personal reasons}

$\begin{array}{ll}\text { Illness } & 0.04\end{array}$

$\begin{array}{ll}\text { Childcare, pregnancy } & 0.10\end{array}$

$\begin{array}{ll}\text { Moved to a new house } & 0.13\end{array}$

$\begin{array}{ll}\text { Studies } & 0.15\end{array}$

$\begin{array}{ll}\text { Wanted to be paid more or try something new } & 0.48\end{array}$

$\begin{array}{ll}\text { Other reasons/uncertain } & 0.10\end{array}$

Source: HUS. 
Table 4 Job Mobility and Geographical Mobility.

Job stayers Quits Layoffs

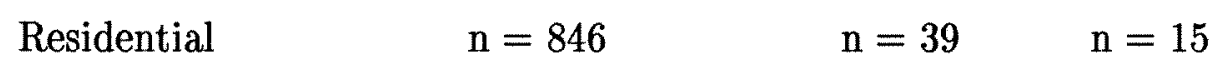

stayers

$\begin{array}{llll}\text { Residential } & \mathrm{n}=140 & \mathrm{n}=28 & \mathrm{n}=9\end{array}$

movers

$$
\chi^{2}=42.71(\text { Prob }=0.000)
$$

Local community

$$
\mathrm{n}=961
$$

$\mathrm{n}=56$

$$
\mathrm{n}=22
$$

stayers

Local community

$$
\mathrm{n}=25
$$

$\mathbf{n}=11$

$\mathrm{n}=2$

movers

$$
\chi^{2}=37.19(\text { Prob }=0.000)
$$

County stayers

$$
\mathrm{n}=977
$$

$\mathrm{n}=61$

$$
\mathrm{n}=23
$$

County movers

$$
\mathrm{n}=9
$$

$\mathrm{n}=6$

$\mathrm{n}=1$

$$
\chi^{2}=28.93(\text { Prob }=0.000)
$$


Even though the propensity for geographical mobility is much higher among those who have changed employer, the majority of geographical movers are job stayers. (A job stayer may, of course, have changed the location of his/her job even though the legal employer is the same.)

\section{The Consequences of Job Mobility}

\section{A. Comparisons Between Job Leavers and Job Loosers}

We now take a look at some consequences of quits and layoffs. Table 5 displays job movers' answers to three different questions about the new job. Among job leavers, 80 percent found a new job within a month whereas the corresponding figure for job loosers was around 60 percent. Around 80 percent of the job leavers found a permanent job, whereas the job loosers found temporary jobs at the same rate as they found permanent ones. The majority of job leavers - and a minority of job loosers report that they have received higher pay on the new job. The numbers do suggest that quits and layoffs are distinct mobility categories. The chi-square statistics show that the consequences of mobility are not independent of the form of the job-change.

These numbers can be compared to those reported by Mortensen and Neumann (1984) using US data. They explored the prevalence of wage cuts in the so called SIME-DIME data (the Seattle-Denver Income Maintenance Experiments). About 30-40 percent of the male job-to-job changers incurred an intial wage cut, and the frequency of wage cuts was higher for job changes that involved spells of non-employment.

Table 6 describes some of the different characteristics of job leavers and job stayers, using observations on employed workers 1984 and 1986. Job leavers are on average much younger than stayers, whereas job loosers are older than job leavers but 
Table 5 Consequences of Quits and Layoffs.

New job within a month?

\begin{tabular}{llc}
\hline & $\underline{\text { YES }}$ & $\underline{\text { NO }}$ \\
Quits & $\mathrm{n}=109$ & $\mathrm{n}=26$ \\
Layoffs & $\mathrm{n}=31$ & $\mathrm{n}=22$ \\
& & $\chi^{2}=10.79($ Prob $<0.005)$ \\
\hline
\end{tabular}

New job permanent?

\begin{tabular}{llc}
\hline & \multicolumn{1}{l}{ YES } & $\underline{\mathrm{NO}}$ \\
Quits & $\mathrm{n}=85$ & $\mathrm{n}=22$ \\
Layoffs & $\mathrm{n}=16$ & $\mathrm{n}=15$ \\
& & $\chi^{2}=9.62($ Prob. $<0.005)$ \\
\hline
\end{tabular}

Higher pay on new job?

\begin{tabular}{llc}
\hline & $\underline{\text { YES }}$ & $\underline{\text { NO }}$ \\
Quits & $\mathrm{n}=62$ & $\mathrm{n}=41$ \\
Layoffs & $\mathrm{n}=13$ & $\mathrm{n}=17$ \\
& & $\chi^{2}=2.71($ Prob $=0.10)$ \\
\hline
\end{tabular}

Source: HUS 
younger than stayers. Women are in these data less likely than men to change jobs, and job leavers have higher education than the other categories. Both work experience and tenure are higher for stayers. Job leavers have spent a slightly larger fraction of the two year period 1984-86 in work than job loosers. Job leavers have around 10 percent lower wage rates than stayers in 1984 , but virtually the same wages in 1986. Job leavers' wage growth was 28 percent during the two-year period; the stayers' wages increased by 18 percent and job loosers' wages increased by 20 percent. (Note that $\Delta \ell \mathrm{ln} \mathrm{w}=.25$ implies 28 percent wage growth since $\exp (.25)=$ 1.28.)

Table 6 Sample Characteristics (means).

\begin{tabular}{lccc}
\hline & Job stayers & Job leavers & Job loosers \\
\hline Age (1984) & 43.3 & 31.5 & 37.3 \\
Woman & 0.50 & 0.40 & 0.42 \\
Schooling (1984) & 11.0 & 2.0 & 11.3 \\
Experience (1984) & 20.6 & 11.5 & 14.8 \\
Tenure (1984) & 11.4 & 4.8 & 4.5 \\
$\Delta$ Experience (1984-86) & 2.11 & 2.10 & 1.98 \\
$\Delta$ Schooling (1984-86) & 0.02 & 0.02 & 0.05 \\
ln w (1984) & 3.80 & 3.71 & 3.66 \\
ln w (1986) & 3.97 & 3.96 & 3.85 \\
$\Delta$ ln w (1984-86) & 0.17 & 0.25 & 0.18 \\
$\mathrm{n}$ & 986 & 67 & 24 \\
\hline
\end{tabular}

Note: $\quad$ Schooling, Experience, Tenure, $\Delta$ Experience and $\Delta$ Schooling are measured in years and woman is a dummy for female workers.

Source: HUS 
These marked differences in wage growth between job leavers and the other workers may, of course, reflect differences in various observable characteristics of the workers. The next section turns to an investigation of this issue by means of estimating wage level and wage growth equations.

\section{B. Wage Regressions}

Our prototype model is a standard human capital earnings function that relates the worker's wage rate to a number of individual attributes. The basic specification is

$$
\begin{gathered}
\text { ln } \mathrm{w}_{\mathrm{i}}=\alpha_{0}+\alpha_{1} \mathrm{WOM}_{\mathrm{i}}+\alpha_{2} \mathrm{AGE}_{\mathrm{i}}+\alpha_{3} \mathrm{AGE}_{\mathrm{i}}^{2} \\
+\alpha_{4} \mathrm{SCHOOL}_{\mathrm{i}}+\alpha_{5} \mathrm{EXP}_{\mathrm{i}}+\alpha_{6} \mathrm{EXP}_{\mathrm{i}}^{2}+\alpha_{7} \mathrm{NS}_{\mathrm{i}}+\epsilon_{\mathrm{i}}
\end{gathered}
$$

where $\ell w_{i}$ is the natural logarithm of the worker's hourly wage rate, WOM $_{i}$ is a dummy for female workers, $\mathrm{SCHOOL}_{\mathrm{i}}$ is years of schooling, $\mathrm{EXP}_{\mathrm{i}}$ is years of work experience, $\mathrm{NS}_{\mathrm{i}}$ is a dummy for persons working nightshift, and $\epsilon_{\mathrm{i}}$ is a stochastic error.

The first column of Table 7 presents estimates of Eq. (1). By and large, the regression performs well and the results appear sensible. The schooling coefficient is estimated to 0.04 , which is close to estimates obtained in other Swedish studies. Women earn about 16 percent less per hour than men, holding constant the standard human capital characteristics. There is also a significant compensating wage differential for individuals working nightshift.

Column (2) of Table 7 includes a dummy, JOBCH, for job movers, and column (3) includes separate dummies for job leavers (QUIT) and job loosers (LAYOFF). Neither of the coefficients of these additional variables become significant at conven- 
tional levels. However, when we proceed to control for the initial wage (i.e., the wage in 1984), the results are different. Most of the human capital variables are very poorly determined when the initial wage is included; this is of course not very surprising since these variables are the major determinants of the initial wage rate. However, the job change variables are much better determined in these specifications. JOBCH is associated with a significant coefficient around 0.05, implying an excess wage growth for movers of 5 percent during this two-year period. Proceeding to column (6), we note that this effect comes from QUIT and not from LAYOFF. The excess wage growth for job leavers amounts to 7 percent, whereas the wage growth of job loosers does not significantly differ from the experiences of stayers.

Our next step involves estimation of wage change equations of the basic form

$$
\begin{aligned}
& \Delta l \mathrm{nw}_{\mathrm{i}}=\beta_{0}+\beta_{1} \mathrm{AGE}_{\mathrm{i}}+\beta_{2} \Delta \mathrm{SCHOOL}_{\mathrm{i}} \\
& +\beta_{3} \Delta \mathrm{EXP}_{\mathrm{i}}+\beta_{4} \Delta \mathrm{EXP}_{\mathrm{i}}^{2}+\beta_{5} \Delta \mathrm{NS}_{\mathrm{i}}+\eta_{\mathrm{i}} .
\end{aligned}
$$

To this equation we add JOBCH, QUIT and LAYOFF, and interactions between the job change variables and tenure in 1984 (TEN84). The results are given in Table 8. In general, the wage growth equations have low explanatory power, but some results are robust. The age-coefficent (which captures the effect from $\mathrm{AGE}^{2}$ in the wage level equation) is significantly negative, and there is also evidence that wage growth increases with acquired work experience, and when a worker switches to nightshift. JOBCH is a significant determinant of wage growth, and again it is QUIT that makes the difference. The regression in column (3) implies an excess wage growth for job leavers of 8 percent, holding constant the observable human capital attributes. Job separations due to layoffs do not involve significant wage improvements. 
Table 7 Estimated Wage Equations. Dependent variable: ln w (1986)

\begin{tabular}{|c|c|c|c|c|c|c|}
\hline & (1) & (2) & (3) & (4) & (5) & (6) \\
\hline Constant & $\begin{array}{r}3.126 \\
(22.68)\end{array}$ & $\begin{array}{r}3.127 \\
(22.56)\end{array}$ & $\begin{array}{r}3.130 \\
(22.61)\end{array}$ & $\begin{array}{c}0.902 \\
(7.939)\end{array}$ & $\begin{array}{c}0.865 \\
(7.578)\end{array}$ & $\begin{array}{c}0.870 \\
(7.633)\end{array}$ \\
\hline WOM & $\begin{array}{c}-0.163 \\
(9.997)\end{array}$ & $\begin{array}{c}-0.163 \\
(9.966)\end{array}$ & $\begin{array}{c}-0.163 \\
(9.975)\end{array}$ & $\begin{array}{c}-0.035 \\
(2.96)\end{array}$ & $\begin{array}{c}-0.032 \\
(2.700)\end{array}$ & $\begin{array}{c}-0.032 \\
(2.715)\end{array}$ \\
\hline $\mathrm{AGE}$ & $\begin{array}{c}0.011 \\
(1.396)\end{array}$ & $\begin{array}{c}0.011 \\
(1.393)\end{array}$ & $\begin{array}{c}0.011 \\
(1.366)\end{array}$ & $\begin{array}{c}0.003 \\
(0.491)\end{array}$ & $\begin{array}{c}0.003 \\
(0.547)\end{array}$ & $\begin{array}{c}0.003 \\
(0.519)\end{array}$ \\
\hline $\mathrm{AGE}^{2} / 1000$ & $\begin{array}{c}-0.098 \\
(1.096)\end{array}$ & $\begin{array}{c}-0.098 \\
(1.094)\end{array}$ & $\begin{array}{c}-0.094 \\
(1.058)\end{array}$ & $\begin{array}{c}-0.041 \\
(0.679)\end{array}$ & $\begin{array}{c}-0.044 \\
(0.724)\end{array}$ & $\begin{array}{c}-0.042 \\
(0.686)\end{array}$ \\
\hline SCHOOL & $\begin{array}{r}0.040 \\
(16.78)\end{array}$ & $\begin{array}{r}0.040 \\
(16.77)\end{array}$ & $\begin{array}{r}0.040 \\
(16.76)\end{array}$ & $\begin{array}{c}0.008 \\
(4.587)\end{array}$ & $\begin{array}{c}0.008 \\
(4.518)\end{array}$ & $\begin{array}{c}0.008 \\
(4.517)\end{array}$ \\
\hline EXP & $\begin{array}{c}0.013 \\
(2.749)\end{array}$ & $\begin{array}{c}0.013 \\
(2.733)\end{array}$ & $\begin{array}{c}0.013 \\
(2.770)\end{array}$ & $\begin{array}{c}0.004 \\
(1.214)\end{array}$ & $\begin{array}{c}0.005 \\
(1.405)\end{array}$ & $\begin{array}{c}0.005 \\
(1.447)\end{array}$ \\
\hline $\mathrm{EXP}^{2} / 1000$ & $\begin{array}{c}-0.181 \\
(2.121)\end{array}$ & $\begin{array}{c}-0.181 \\
(2.112)\end{array}$ & $\begin{array}{c}-0.184 \\
(2.152)\end{array}$ & $\begin{array}{c}-0.065 \\
(1.121)\end{array}$ & $\begin{array}{c}-0.074 \\
(1.270)\end{array}$ & $\begin{array}{c}-0.077 \\
(1.315)\end{array}$ \\
\hline NS & $\begin{array}{c}0.094 \\
(2.196)\end{array}$ & $\begin{array}{c}0.093 \\
(2.191)\end{array}$ & $\begin{array}{c}0.092 \\
(2.173)\end{array}$ & $\begin{array}{c}-0.003 \\
(0.107)\end{array}$ & $\begin{array}{c}-0.001 \\
(0.029)\end{array}$ & $\begin{array}{c}-0.001 \\
(0.047)\end{array}$ \\
\hline $\ln \mathrm{w}(1984)$ & - & - & - & $\begin{array}{r}0.765 \\
(34.92)\end{array}$ & $\begin{array}{c}0.769 \\
(35.11)\end{array}$ & $\begin{array}{r}0.768 \\
(35.11)\end{array}$ \\
\hline JOBCH & - & $\begin{array}{c}-0.002 \\
(0.060)\end{array}$ & - & & $\begin{array}{c}0.048 \\
(2.561)\end{array}$ & - \\
\hline QUIT & - & - & $\begin{array}{c}0.028 \\
(0.912)\end{array}$ & & - & $\begin{array}{c}0.069 \\
(3.265)\end{array}$ \\
\hline LAYOFF & - & - & $\begin{array}{c}-0.083 \\
(1.679)\end{array}$ & & - & $\begin{array}{c}-0.012 \\
(0.351)\end{array}$ \\
\hline$\overline{\mathrm{R}}^{2}$ & 0.331 & 0.330 & 0.332 & 0.688 & 0.690 & 0.691 \\
\hline $\mathrm{n}$ & 1069 & 1069 & 1069 & 1069 & 1069 & 1069 \\
\hline
\end{tabular}

Note: $\quad$ Absolute $t-v a l u e s$ are in the parentheses. 
Table 8 Estimated Wage Growth Equations, 1984-86. Dependent variable: $\Delta \ell \mathrm{ln}$.

\begin{tabular}{|c|c|c|c|c|c|c|}
\hline & $(1)$ & (2) & (3) & (4) & $(5)$ & (6) \\
\hline Constant & $\begin{array}{c}0.211 \\
(4.062)\end{array}$ & $\begin{array}{c}0.185 \\
(3.547)\end{array}$ & $\begin{array}{c}0.184 \\
(3.520)\end{array}$ & $\begin{array}{c}0.178 \\
(3.407)\end{array}$ & $\begin{array}{c}0.176 \\
(3.367)\end{array}$ & $\begin{array}{c}0.173 \\
(3.313)\end{array}$ \\
\hline WOM & $\begin{array}{c}0.010 \\
(0.906)\end{array}$ & $\begin{array}{c}0.013 \\
(1.171)\end{array}$ & $\begin{array}{c}0.013 \\
(1.158)\end{array}$ & $\begin{array}{c}0.013 \\
(1.110)\end{array}$ & $\begin{array}{c}0.012 \\
(1.046)\end{array}$ & $\begin{array}{c}0.012 \\
(1.024)\end{array}$ \\
\hline $\mathrm{AGE}$ & $\begin{array}{c}-0.003 \\
(2.713)\end{array}$ & $\begin{array}{c}-0.002 \\
(2.482)\end{array}$ & $\begin{array}{c}-0.002 \\
(2.404)\end{array}$ & $\begin{array}{c}-0.002 \\
(2.423)\end{array}$ & $\begin{array}{c}-0.002 \\
(2.368)\end{array}$ & $\begin{array}{c}-0.002 \\
(2.280)\end{array}$ \\
\hline$\triangle \mathrm{SCHOOL}$ & $\begin{array}{c}0.011 \\
(0.306)\end{array}$ & $\begin{array}{c}0.010 \\
(0.282)\end{array}$ & $\begin{array}{c}0.009 \\
(0.254)\end{array}$ & $\begin{array}{c}0.012 \\
(0.333)\end{array}$ & $\begin{array}{c}0.009 \\
(0.264)\end{array}$ & $\begin{array}{c}0.008 \\
(0.229)\end{array}$ \\
\hline$\triangle \mathrm{EXP}$ & $\begin{array}{c}0.028 \\
(1.470)\end{array}$ & $\begin{array}{c}0.031 \\
(1.598)\end{array}$ & $\begin{array}{c}0.031 \\
(1.581)\end{array}$ & $\begin{array}{c}0.033 \\
(1.726)\end{array}$ & $\begin{array}{c}0.033 \\
(1.695)\end{array}$ & $\begin{array}{c}0.033 \\
(1.703)\end{array}$ \\
\hline$\Delta \mathrm{EXP}^{2}$ & $\begin{array}{r}0.0001 \\
(0.535)\end{array}$ & $\begin{array}{c}0.0002 \\
(0.713)\end{array}$ & $\begin{array}{c}0.0002 \\
(0.670)\end{array}$ & $\begin{array}{c}0.0002 \\
(0.333)\end{array}$ & $\begin{array}{c}0.0002 \\
(0.764)\end{array}$ & $\begin{array}{c}0.0002 \\
(0.719)\end{array}$ \\
\hline$\Delta \mathrm{NS}$ & $\begin{array}{c}0.081 \\
(2.329)\end{array}$ & $\begin{array}{c}0.088 \\
(2.537)\end{array}$ & $\begin{array}{c}0.087 \\
(2.502)\end{array}$ & $\begin{array}{c}0.089 \\
(2.564)\end{array}$ & $\begin{array}{c}0.091 \\
(2.621)\end{array}$ & $\begin{array}{c}0.089 \\
(2.583)\end{array}$ \\
\hline JOBCH & - & $\begin{array}{c}0.066 \\
(3.422)\end{array}$ & - & $\begin{array}{c}0.072 \\
(3.712)\end{array}$ & $\begin{array}{c}0.107 \\
(4.346)\end{array}$ & - \\
\hline QUIT & - & - & $\begin{array}{c}0.084 \\
(3.792)\end{array}$ & - & - & $\begin{array}{c}0.138 \\
(4.542)\end{array}$ \\
\hline LAYOFF & - & - & $\begin{array}{c}0.017 \\
(0.485)\end{array}$ & - & - & $\begin{array}{c}0.041 \\
(1.020)\end{array}$ \\
\hline JOBCH*TEN84 & - & - & - & - & $\begin{array}{c}-0.007 \\
(2.300)\end{array}$ & - \\
\hline QUIT*TEN84 & - & - & - & - & - & $\begin{array}{r}-0.0094 \\
(2.196)\end{array}$ \\
\hline LAYOFF ${ }^{*}$ TEN84 & $4-$ & - & - & - & - & $\begin{array}{r}-0.0054 \\
(1.143)\end{array}$ \\
\hline$\overline{\mathrm{R}}^{2}$ & 0.020 & 0.030 & 0.032 & 0.034 & 0.036 & 0.038 \\
\hline $\mathrm{n}$ & 1069 & 1069 & 1069 & 1063 & 1063 & 1063 \\
\hline
\end{tabular}

Note: $\quad$ Absolute $t-v a l u e s$ are in parentheses. 
The three last columns of Table 8 show regressions on observations with nonmissing values for TEN84. Column (4) replicates the regression in column (2), and interactions between job change variables and tenure are introduced in columns (5) and (6). The results show that wage gains are dependent on tenure; the excess wage growth for job leavers with zero tenure is 14 percent, but only 5 percent for workers with 10 years of tenure.

Table 9 shows effects of including alternative measures of geographical mobility in wage change regressions. The estimations indicate very small wage effects of residential and local community mobility. The estimated coefficients are not significantly different from zero, and 95 percent confidence intervals are in the range between -.05 to +.05 . On the other hand, it cannot be ruled out that there are marked effects of long distance mobility, i.e., migration between counties, even when job mobility is controlled for; a 95 percent confidence interval for the coefficient for county mobility is in the range between -.05 to +.11 (according to column (6) in Table 9). The small size of the sample contributes to the low precision of the estimates.

Table 10 provides additional information about the age-pattern of wage gains. As found in other studies, there is indeed a distinct age-pattern in wage gains to mobility. The excess wage growth for "young" workers is 11 percent, and the corresponding figure for workers over 45 is only 2 percent (and insignificantly different from zero). 
$\underline{\underline{T a b l e} 9}$ The Effects of Job Mobility and Geographical Mobility.

\begin{tabular}{|c|c|c|c|c|c|c|}
\hline & (1) & (2) & (3) & (4) & (5) & (6) \\
\hline QUIT & - & $\begin{array}{c}0.083 \\
(3.706)\end{array}$ & - & $\begin{array}{c}0.086 \\
(3.848)\end{array}$ & - & $\begin{array}{c}0.082 \\
(3.653)\end{array}$ \\
\hline LAYOFF & - & $\begin{array}{c}0.016 \\
(0.450)\end{array}$ & - & $\begin{array}{c}0.018 \\
(0.513)\end{array}$ & - & $\begin{array}{c}0.016 \\
(0.462)\end{array}$ \\
\hline $\begin{array}{l}\text { Residential } \\
\text { mobility }\end{array}$ & $\begin{array}{c}0.013 \\
(0.915)\end{array}$ & $\begin{array}{c}0.006 \\
(0.438)\end{array}$ & - & - & - & - \\
\hline $\begin{array}{l}\text { Local community } \\
\text { mobility }\end{array}$ & y & - & -0.0005 & $\begin{array}{c}-0.0190 \\
(0.665)\end{array}$ & - & - \\
\hline County mobility & - & - & - & - & $\begin{array}{c}0.053 \\
(1.221)\end{array}$ & $\begin{array}{c}0.030 \\
(0.681)\end{array}$ \\
\hline $\mathrm{R}^{2}$ & 0.020 & 0.031 & 0.019 & 0.031 & 0.021 & 0.031 \\
\hline $\mathrm{n}$ & 1069 & 1069 & 1069 & 1069 & 1069 & 1069 \\
\hline
\end{tabular}

Note: The table shows estimated coefficients (with t-values) for various dummy-variables for job changes and geographical mobility

Table 10 Excess Wage Growth for Job Changers, by age.

\begin{tabular}{lccc}
\hline & $\begin{array}{c}\text { AGE } \leq 30 \\
(\mathrm{n}=151)\end{array}$ & $\begin{array}{l}30<\mathrm{AGE} \leq 45 \\
(\mathrm{n}=514)\end{array}$ & $\begin{array}{l}\text { AGE }>45 \\
(\mathrm{n}=402)\end{array}$ \\
\hline JOBCH & 0.081 & 0.067 & 0.025 \\
& $(2.067)$ & $(2.774)$ & $(0.428)$ \\
QUIT & 0.111 & 0.079 & 0.020 \\
& $(2.478)$ & $(2.985)$ & $(0.246)$ \\
LAYOFF & 0.012 & 0.012 & 0.030 \\
& $(0.182)$ & $(0.212)$ & $(0.364)$ \\
\hline
\end{tabular}

Note: The table shows estimated coefficients (with t-values) of job change dummies in wage growth equations, the latter estimated separately for the two age groups. 


\section{Conclusions}

We have used a new Swedish data set to shed light on some basic features of job mobility. The period of investigation is the two-year period from spring 1984 to spring 1986, and the major conclusions are as follows:

(i) The vast majority of job terminations consists of employee-initiated separations. Some 70 percent of the quitters left permanent jobs, and 30 percent left jobs with a pre-determined length (temporary jobs). There is little evidence that quits in general are "disguised layoffs". The majority of quits have causes related to working conditions. Some 40 percent of the job leavers also changed residence. The pullincentives appear to be quite important in the Swedish labor market, despite the substantial pay compression that has taken place during the past two decades

(ii). The data clearly reveal that quits and layoffs have different consequences. Job leavers find new jobs more rapidly than job loosers, and job leavers find permanent jobs more often than job loosers do. A majority of job leavers - and a minority of job loosers - report that they have received higher pay on the new job. In addition, wage regressions show significant differences in wage growth between job leavers on the one hand, and job loosers and job stayers on the other hand. The excess wage growth for job leavers is 7-8 percent; there is no evidence suggesting that employer-initiated job separations involve (positive or negative) wage effects. These findings suggest that quits and layoffs should be treated differently in models of job mobility.

(iii) The data reveal that wage gains to mobility are decreasing in length of tenure, and there is also a clear age-pattern in wage gains. The excess wage growth for job 
leavers under age 30 is 11 percent, whereas the wage gain for job leavers over 45 is only 2 percent (and insignificantly different from zero.)

(iv) There is no evidence that geographical mobility involves substantial wage gains in addition to those obtained by changing employer. 


\section{REFERENCES}

Burdett, K., "A Theory of Employee Search and Quit Rates". American Economic Review, 68, 212-220.

Flanagan, R.J., (1987), "Efficiency and Equality in Swedish Labor Markets". In B.P. Bosworth and A.M. Rivlin (eds), The Swedish Economy. Washington: The Brookings Institution.

Holmlund, B., (1984a), Labor Mobility. Stockholm: The Industrial Institute for Economic and Social Research.

Holmlund, B., (1984b), "Income Prospects and Job Mobility: The Case of Sweden." Euopean Economic Review, 24, 383-400.

Holmlund, B., and Lang, H., (1985), "Quit Behavior under Imperfect Information: Searching, Moving, Learning." Economic Inquiry, XXIII, 383-393.

Klevmarken, A., (1984), "Household market and nonmarket activities. The first year of a Swedish panel study." The 1984 Business and Economic Statistics Section Proceedings of the American Statistical Association and Vierteliahnshefte zur Wirtschaftsforschung Heft 4 1984, Deutsches Institut fur Wirtschaftsforschung.

Klevmarken, A., Olovsson, P., and Flood, L., (1986), "Hushållens ekonomiska levnadsförhållanden. Teknisk beskrivning och kodbok för 1984 års HUS-data." Department of Economics, University of Göteborg.

Mortensen, D.T., (1978), "Specific Capital and Labor Turnover". Bell Journal of Economics, 9, 572-586.

Mortensen, D.T., and Neumann, G.R., (1984), "Inter-firm Mobility and Earnings". Preliminary draft, November.

Parsons, D.O., (1972), "Specific Human Capital: An Application to Quit Rates and Layoff Rates". Journal of Political Economy, 80, 1120-1143.

Rundblad, B., (1964), Arbetskraftens rörlighet. (The Mobility of Labor). Stockholm: The Industrial Institute for Economic and Social Research. 